\title{
What can hedonic motivation do on decisions to use online learning services?
}

\author{
Hartelina $^{a^{*}}$, Reminta Lumban Batu ${ }^{a}$ and Ayuk Hidayantia
}

\begin{tabular}{l}
$\frac{{ }^{a} \text { Faculty of Economics, Universitas Si }}{\text { C H R O N I C L E }}$ \\
\hline Article history: \\
Received: September 20, 2020 \\
Received in revised format: \\
January 15, 2021 \\
Accepted: January 16, 2021 \\
Available online: January 16, 2021 \\
\hline Keywords: \\
Hedonic motivation \\
Decisions to use \\
Behavioral intention \\
Online learning \\
Services \\
\hline
\end{tabular}
\begin{abstract}
A B S T R A C T
The advancement of the internet and technology encourages the creation of innovations in various industries in Indonesia. Technology is the key determinant of the competitiveness of the 4.0 industrial revolution so that every organization and individual, including educators and students, can achieve many things. Online-based learning systems result in changes in the behavior of Indonesian consumers who choose learning without time and space boundaries. This study aims to determine how hedonic motivation can influence decisions to use online learning services. This research used quantitative analysis through a survey method that is processed using SMART PLS. The results of this study indicate that hedonic motivation will first influence purchase intention and then influence the decision to use services.
\end{abstract}

Sarawang, Indonesia

\section{Introduction}

The 21 st century is the beginning of the industrial revolution 4.0. The industrial revolution 4.0 automatically occurs in all areas of life, one of which is education (Ghufron, 2018). The presence of the 4.0 industrial revolution directs current education to a more modern education. One of the advances in technology in the modern education system is e-learning (Bates \& Bates, 2005; Agarwal \& Pandey, 2013). A teacher in a society is a highly respected individual, and teaching is considered the most important and distinctive profession. How effective instructors are is very much linked to how they communicate. They express ideas, information and expectations in a number of ways: by speaking, by gestures and other body language, and by written words (Duta et al., 2015). Motivation is considered the most important theory in UTAUT2 because it integrates the much-needed affective component into UTAUT (Tamilmani et al., 2019). Motivation is defined as the pleasure obtained from the use of technology (Tamilmani et al., 2019). Apart from using technology for productive purposes, the use of technology has also become a lifestyle such as playing computer games, streaming music, instant messaging (Tamilmani et al., 2019) and online learning (Isaac et al., 2019). The population of smartphone owners continues to grow, with it is estimated that in 2019, the number of smartphone users worldwide will exceed 5 billion (Shaw \& Sergueeva, 2019). The advancement of the internet and technology encourages the creation of innovations in various industries in Indonesia. Technology is the key determinant of the competitiveness of the 4.0 industrial revolution so that every organization and individual, including educators and students, can achieve many things. Online-based learning systems result in changes in the behavior of Indonesian consumers who choose learning without time and space boundaries (Sari, 2012). Data from the Ministry of Information and Technology states that internet users in Indonesia have reached 143.26 billion people in 2017. The importance of using technology for education makes material management more effective and efficient. Indonesian students rank first and second in the use of IT/computers in schools as much as $40 \%$ and $54 \%$ after the United States. Online learning provides a flexible schedule where students can access it whenever they want and it is easy for students to access (Isaac et al., 2019; Aziz, 2019). There are various learning applications that can make it easier for students and students to do online learning including: Teacher's Room, 
Quipper, Zenius, EduLab, edmodo, learning houses and other applications such as applications provided by schools or campuses. This study aims to determine how hedonic motivation can influence decisions to use online learning services.

\section{Literature Review and Hypothesis}

Digitalization is reconfiguring retailing (Fuentes et al., 2017). This retail transformation is not only changing the channel of transaction but is redefining the nature and types of exchanges, actors, offerings, and retail settings (Hagberg et al., 2016). Information and Communication Technology (ICT) in the late 20th century, technology users were mostly used only for an organization (Tamilmani et al., 2019). The development of information technology has developed rapidly in the current era of globalization (Budiman, 2017). The era of globalization has triggered a shift in the world of education from face-to-face meetings to conventional (Budiman, 2017) online environments (Alawamleh et al., 2020). Technological advances are expected to create better things and improve the quality of life as seen from seamless connectivity, full optimization, expanded reality, broadening horizons so that the use of intelligent technology in education represents the application of online learning. Online learning is defined as the use of digital gadgets (laptops, desktop computers, tablets, and smartphones) in their use of the internet (Isaac et al., 2019). In this context, previous studies show that drawing on the Unified Theory of Acceptance and Use of Technology 2 (UTAUT2) Model, this study aimed to determine the key variables that facilitate the acceptance of mobile learning in two Middle Eastern countries (Saudi Arabia and Iraq), as well as identifying the constructs that can help enhance learners' motivation. A conceptual framework was proposed based on a modified UTAUT2, wherein trust was integrated, and new relationships were assumed among the proposed Model variables (Al-Azawei \& Alowayr, 2020). Previous research also tells that hedonic motivation adoption frameworks with flow state and subjective well-being have been shown to have significant roles in continued use of information technology (Salimon et al., 2017; Oluwajana et al., 2019; Lowry et al., 2012; Alalwan et al., 2015; Sharif \& Raza, 2017; Baabdullah, 2018; Kim and Hall, 2019). Hedonic shopping motivation presents behavior that is related to fun, amusement, fantasy, and the sensorial stimuli aspects of consumption (Babin et al., 1994). HM is defined as a key predictor of intention to purchase in consumer behavior research (Holbrook and Hirschman, 1982) and has recently also been associated with customer satisfaction and loyalty (Vieira et al., 2018). Purchase decisions are the science of meeting their needs and wants about how individuals, groups and organizations choose, buy, and use goods, services, ideas, or experiences. Another definition of a buying decision according to states that a buying decision is the selection of an action from two or more alternative options. According to decision making, it is an individual activity that is directly involved in obtaining and using the goods offered (Parment et al, 2016; Sangadji, 2013, Evita \& Farochi, 2017).

The existing literature predicts the factors that can determine hedonic motivation, which was not included in the original Unified Theory of Acceptance and Use of Technology (UTAUT2). It also integrates 'trust' with UTAUT2 as another predictor of behavioral intention and hedonic motivation (Al-Azawei \& Alowayr, 2020). UTAUT2 has 7 main factors, namely: performance expectancy, effort expectancy, social influence, facilitating conditions (Handayani \& Sudiana, 2017) hedonic motivation, price value and habit (Tamilmani et al., 2019). The formulation of the problem of this study is to determine how much influence hedonic motivation has on behavioral intention in online learning applications, how much influence does behavioral intention have on use behavior in online learning applications. This study aims to determine how much influence hedonic motivation has on behavioral intention in online learning applications, how much influence does behavioral intention have on use behavior in online learning applications.

\section{$\mathbf{H}_{1}$ : Hedonic Motivation has a positive and significant effect on Behavioral Intention in online learning applications. \\ $\mathbf{H}_{2}$ : Behavioral Intention has a positive and significant effect on Use Behavior in online learning applications. \\ H3: Hedonic Motivation has a positive and significant effect on Use Behavior through Behavioral Intention in online learning applications.}

\section{Method and Material}

This research used quantitative research. The quantitative method is carried out by means of a survey to find out the respondents from the research subject. The population of this study were users of online learning applications in Indonesia. The samples in this study were users of the Guru Room, Quipper, Zenius, EduLab, Edmodo, learning houses and other applications from school/campus. Data collection techniques in this study were taken from library research, questionnaires, and documentation. This research test was conducted using PLS (Partial Least Square). The data analysis technique of this research uses descriptive analysis and verification. Descriptive analysis was carried out by distributing questionnaires to respondents in order to obtain a description of the research variables. Verification analysis was performed using SEM - PLS. This study uses the SmartPLS3 program to connect latent variables with manifest.

\section{Result}

The result showed that the composite reliability value for each indicator is above 0.7 (Table 1). This means that the indicators of each variable of behavioral intention, hedonic motivation, and use behavior can be said to have good reliability as a measuring tool. Table 2 shows that the AVE value in all variables is above 0.5 , meaning that all variables are said to be convergent valid. The AVE value on the behavioral intention $(\mathrm{X})$ variable is 0.269 , meaning that on average $62.9 \%$ of the information contained in each indicator can be represented through the latent behavioral intention variable. The AVE value on the hedonic motivation $(\mathrm{Y})$ variable is 0.71 , meaning that on average $71 \%$ of the information contained in each indicator can be represented 
through the latent hedonic motivation variable. The AVE value in the use behavior variable $(\mathrm{Z})$ is 0.611 , meaning that on average $61.1 \%$ of the information contained in each indicator can be represented through the latent use behavior variable.

Table 1

Composite Reliability (CR)

\begin{tabular}{lll}
\hline Variables & Cronbach's Alpha & Composite Reliability \\
\hline Behavioral Intention & 0.901 & 0.922 \\
Hedonic Motivation & 0.918 & 0.936 \\
Use Behavior & 0.893 & 0.916 \\
\hline
\end{tabular}

Table 2

Average Variance Extracted (AVE)

\begin{tabular}{ll}
\hline Variables & Average Variance Extracted (AVE) \\
\hline Behavioral Intention & 0.629 \\
Hedonic Motivation & 0.71 \\
Use Behavior & 0.611 \\
\hline
\end{tabular}

The results show that hedonic motivation has a positive effect of $80.7 \%$ on behavioral intention. The hedonic motivation variable has a positive effect on use behavior of $82.6 \%$ (Table 3; Fig. 1 ).

Table 3

Outer loadings

\begin{tabular}{|c|c|c|c|c|c|}
\hline & (O) & (M) & (STDEV) & (|O/STDEV $\mid)$ & $p$-values \\
\hline $\mathrm{X} 1.2 \leftarrow$ Hedonic Motivation & 0.861 & 0.858 & 0.031 & 27.572 & $* * *$ \\
\hline X1.3 $\leftarrow$ Hedonic Motivation & 0.817 & 0.816 & 0.05 & 16.383 & $* * *$ \\
\hline $\mathrm{X} 1.4 \leftarrow$ Hedonic Motivation & 0.831 & 0.829 & 0.037 & 22.395 & $* * *$ \\
\hline X1.5 $\leftarrow$ Hedonic Motivation & 0.838 & 0.84 & 0.042 & 20.019 & $* * *$ \\
\hline \multirow[t]{2}{*}{ X1.6 $\leftarrow$ Hedonic Motivation } & 0.831 & 0.832 & 0.035 & 23.737 & $* * *$ \\
\hline & (O) & (M) & (STDEV) & (|O/STDEV|) & p-svalues \\
\hline Y1 $\leftarrow$ Behavioral Intention & 0.73 & 0.725 & 0.061 & 11.953 & $* * *$ \\
\hline $\mathrm{Y} 2 \leftarrow$ Behavioral Intention & 0.791 & 0.792 & 0.055 & 14.267 & $* * *$ \\
\hline $\mathrm{Y} 3 \leftarrow$ Behavioral Intention & 0.758 & 0.753 & 0.055 & 13.765 & $* * *$ \\
\hline Y4 $\leftarrow$ Behavioral Intention & 0.859 & 0.858 & 0.028 & 30.72 & $* * *$ \\
\hline Y5 $\leftarrow$ Behavioral Intention & 0.848 & 0.849 & 0.03 & 28.227 & $* * *$ \\
\hline Y $6 \leftarrow$ Behavioral Intention & 0.742 & 0.741 & 0.056 & 13.284 & $* * *$ \\
\hline Y7 $\leftarrow$ Behavioral Intention & 0.812 & 0.809 & 0.044 & 18.647 & $* * *$ \\
\hline $\mathrm{Z} 1 \leftarrow$ Use Behavior & 0.81 & 0.809 & 0.032 & 25.31 & $* * *$ \\
\hline $\mathrm{Z} 2 \leftarrow$ Use Behavior & 0.863 & 0.863 & 0.023 & 37.585 & $* * *$ \\
\hline $\mathrm{Z} 3 \leftarrow$ Use Behavior & 0.79 & 0.786 & 0.043 & 18.186 & $* * *$ \\
\hline Z4 $\leftarrow$ Use Behavior & 0.735 & 0.737 & 0.052 & 14.02 & $* * *$ \\
\hline $\mathrm{Z} 5 \leftarrow$ Use Behavior & 0.706 & 0.704 & 0.058 & 12.146 & $* * *$ \\
\hline Z6 $\leftarrow$ Use Behavior & 0.818 & 0.814 & 0.049 & 16.569 & $* * *$ \\
\hline $\mathrm{Z} 7 \leftarrow$ Use Behavior & 0.739 & 0.737 & 0.066 & 11.126 & $* * *$ \\
\hline $\mathrm{X} 1.1 \leftarrow$ Hedonic Motivation & 0.877 & 0.875 & 0.024 & 37.256 & $* * *$ \\
\hline
\end{tabular}

Table 3 shows that all indicators of each variable, namely hedonic motivation, behavioral intention, and use behavior have a loading factor above 0.5 so that it can be seen that all indicators of the hedonic motivation, behavioral intention, and use behavior variables are valid. as an indicator to measure each construct/variable.

Table 4

R-Square Test

\begin{tabular}{lll}
\hline Behavioral Intention & R Square & R Square Adjusted \\
\hline Use Behavior & 0.651 & 0.647 \\
& 0.683 & 0.68 \\
\hline
\end{tabular}

According to Vincenco (2010), the R-Square criterion of 0.67 is strong, 0.33 is moderate, 0.19 is weak. According to Chin (1998), the value of R Square is said to be strong if the value is 0.67, it is said to be moderate if the value is 0.33 and it is said to be weak if the value is 0.19 . Based on the table above, the results of R-Square (R2) behavioral intention are 0.651 , so the $\mathrm{R}$ square value is said to be moderate. The R-Square value of the use behavior variable is 0.683 , so the $\mathrm{R}$ Square value is said to be strong. The testing shows that hedonic motivation has a significant effect on use behavior through behavioral intention in accordance with research (Al-Azawei \& Alowayr, 2020) which states that hedonic motivation is a strong predictor of 
behavioral intention to use online learning. In term of the influence of hedonic motivation on use behavior, based on the results of the study, it is known that hedonic motivation has a significant effect on use behavior according to Shaw and Sergueeva (2019) which states that performance expectancy and privacy concerns both significantly affect perceived value and the value of perceived value and hedonic motivation has a strong effect on use behavior. Additionally, the hypothesis testing about the influence of hedonic motivation on behavioral intention revealed that hedonic motivation has a significant effect on behavioral intention. This is in line with Putri and Suardikha (2020), which states that facilitating condition variables, hedonic motivation, and price value influence the intention to use e-money.

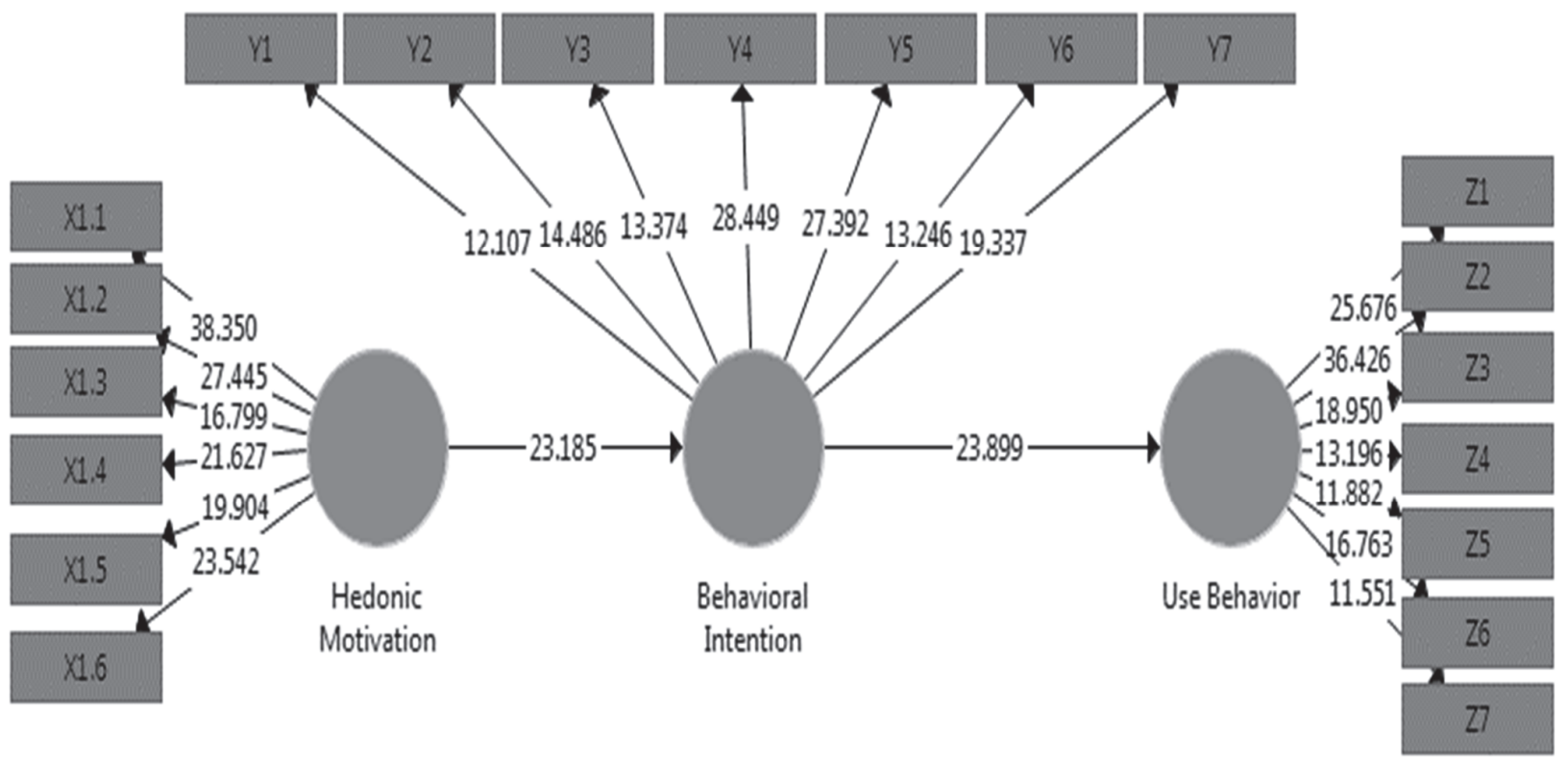

Fig. 1. Full Model

\section{Conclusion}

The results have shown that hedonic motivation had a positive and significant effect on behavioral intention in online learning applications. This shows that the positive and significant effect of hedonic motivation on behavioral intention in online learning applications is declared acceptable. Moreover, behavioral intention has a positive and significant effect on use behavior in online learning applications. This shows that the hypothesis stating that behavioral intention has a positive and significant effect on use behavior in online learning applications is declared acceptable. Hedonic motivation has a positive and significant effect on use behavior through behavioral intention in online learning applications. This shows that the hypothesis stating that social influence has a positive and significant effect on use behavior through behavioral intention is acceptable.

\section{References}

Agarwal, H., \& Pandey, G. N. (2013). Impact of E-learning in education. International Journal of Science and Research (IJSR), 2(12), 146-147.

Alalwan, A. A., Dwivedi, Y. K., Rana, N. P., Lal, B., \& Williams, M. D. (2015). Consumer adoption of Internet banking in Jordan: Examining the role of hedonic motivation, habit, self-efficacy and trust. Journal of Financial Services Marketing, 20(2), 145-157.

Alawamleh, M., Al-Twait, L. M., \& Al-Saht, G. R. (2020). The effect of online learning on communication between instructors and students during Covid-19 pandemic. Asian Education and Development Studies.

Al-Azawei, A., \& Alowayr, A. (2020). Predicting the intention to use and hedonic motivation for mobile learning: A comparative study in two Middle Eastern countries. Technology in Society, 62, 101325.

Aziz, A. (2019). Applying Theory of Planned Behavior to Understand Pro-Environmental Intention and Behavior of Students. Arthatama, 3(1), 1-15.

Baabdullah, A. M. (2018). Consumer adoption of Mobile Social Network Games (M-SNGs) in Saudi Arabia: The role of social influence, hedonic motivation and trust. Technology in Society, 53, 91-102.

Babin, B. J., Darden, W. R., \& Griffin, M. (1994). Work and/or fun: measuring hedonic and utilitarian shopping value. Journal of consumer research, 20(4), 644-656.

Bates, A. W., \& Bates, T. (2005). Technology, e-learning and distance education. Psychology Press.

Budiman, H. (2017). Peran teknologi informasi dan komunikasi dalam pendidikan. Al-Tadzkiyyah: Jurnal Pendidikan Islam, 8(1), 31-43. 
Duta, N., Panisoara, G., \& Panisoara, I. O. (2015). The Effective Communication in Teaching. Diagnostic study regarding the academic learning motivation to students. Procedia-Social and Behavioral Sciences, 186, 1007-1012.

Evita, N., \& Farochi, C. (2017). Pengaruh Citra Merek Terhadap Keputusan Pembelian (Studi Kasus Pada Bakso Boedjangan Cabang Burangrang Bandung Tahun 2017). eProceedings of Applied Science, 3(2).

Fuentes, C., Bäckström, K., \& Svingstedt, A. (2017). Smartphones and the reconfiguration of retailscapes: Stores, shopping, and digitalization. Journal of Retailing and Consumer Services, 39, 270-278.

Ghufron, G. (2018, September). Revolusi Industri 4.0: Tantangan, Peluang, Dan Solusi Bagi Dunia Pendidikan. In Seminar Nasional dan Diskusi Panel Multidisiplin Hasil Penelitian dan Pengabdian Kepada Masyarakat 2018 (Vol. 1, No. 1).

Hagberg, J., Sundström, M., \& Nicklas, E. Z. (2016). The digitalization of retailing: an exploratory framework. International Journal of Retail \& Distribution Management, 44(7), 694-712.

Holbrook, M. B., \& Hirschman, E. C. (1982). The experiential aspects of consumption: Consumer fantasies, feelings, and fun. Journal of consumer research, $9(2), 132-140$.

Isaac, O., Aldholay, A., Abdullah, Z., \& Ramayah, T. (2019). Online learning usage within Yemeni higher education: The role of compatibility and task-technology fit as mediating variables in the IS success model. Computers \& Education, 136, 113-129.

Kim, M. J., \& Hall, C. M. (2019). A hedonic motivation model in virtual reality tourism: Comparing visitors and non-visitors. International Journal of Information Management, 46, 236-249.

Lowry, P. B., Gaskin, J., Twyman, N., Hammer, B., \& Roberts, T. (2012). Taking 'fun and games' seriously: Proposing the hedonic-motivation system adoption model (HMSAM). Journal of the Association for Information Systems, 14(11), 617671.

Oluwajana, D., Idowu, A., Nat, M., Vanduhe, V., \& Fadiya, S. (2019). The Adoption of Students' Hedonic Motivation System Model to Gamified Learning Environment. Journal of theoretical and applied electronic commerce research, 14(3), 0-0.

Parment, A., Kotler, P., \& Armstrong, G. (2016). Principles of marketing: Scandinavian edition. Pearson Education Limited.

Putri, N. K. R. D., \& Suardikha, I. M. S. (2019). Penerapan Model UTAUT 2 Untuk Menjelaskan Niat Dan Perilaku Penggunaan E-Money di Kota Denpasar. E-Jurnal Akuntansi, 30(2), 540-555.

Salimon, M. G., Yusoff, R. Z. B., \& Mokhtar, S. S. M. (2017). The mediating role of hedonic motivation on the relationship between adoption of e-banking and its determinants. International Journal of Bank Marketing, 35(4), 558-582.

Sangadji, E. M. (2013). Perilaku Konsumen: Pendekatan Praktis. Yogyakarta: Andi Yogyakarta.

Sari, E. R. (2012). Online learning community: A case study of teacher professional development in Indonesia. Intercultural Education, 23(1), 63-72.

Sharif, A., \& Raza, S. A. (2017). The influence of hedonic motivation, self-efficacy, trust and habit on adoption of internet banking: a case of developing country. International Journal of Electronic Customer Relationship Management, 11(1), 122.

Shaw, N., \& Sergueeva, K. (2019). The non-monetary benefits of mobile commerce: Extending UTAUT2 with perceived value. International Journal of Information Management, 45, 44-55.

Shoumi, A. Z. (2019, October). Peran multimedia dalam pendidikan pada aplikasi ruang guru. Prosiding seminar nasional cendekiawan (pp. 2-23).

Tamilmani, K., Rana, N. P., Prakasam, N., \& Dwivedi, Y. K. (2019). The battle of Brain vs. Heart: A literature review and meta-analysis of "hedonic motivation" use in UTAUT2. International Journal of Information Management, 46, $222-235$.

Taqwatika, S., Agustini, K., \& Suyasa, P. W. A. (2019). Analisis Penerimaan Sistem Pembelajaran Online Edmodo Menggunakan Unified Theory of Acceptance and Use of Technology (UTAUT) Studi Kasus: Kelas IX di SMP Negeri 1 Singaraja)". Karmapati (Kumpulan Artikel Mahasiswa Pendidikan Teknik Informatika), 8(2), 467-475.

Vieira, V., Santini, F. O., \& Araujo, C. F. (2018). A meta-analytic review of hedonic and utilitarian shopping values. Journal of Consumer Marketing, 35(4), 426-437. 
(C) 2021 by the authors; licensee Growing Science, Canada. This is an open access article distributed under the terms and conditions of the Creative Commons Attribution (CC-BY) license (http://creativecommons.org/licenses/by/4.0/). 